\title{
Risk factors for sexually transmitted diseases among sex workers in the interior of Piaui, Brazil
}

\author{
Fatores de risco para doenças sexualmente transmissiveis \\ em profissionais do sexo do interior piauiense \\ Factores de riesgo de enfermedades de transmisión sexual \\ en el trabajadoras sexuales en interior piauiense
}

\author{
Jardeliny Corrêa da Penha ${ }^{a}$ \\ Caroline Batista de Queiroz Aquino ${ }^{b}$ \\ Érica de Alencar Rodrigues Neric \\ Thaís Gomes Oliveira dos Reis ${ }^{\mathrm{d}}$ \\ Priscila de Souza Aquino ${ }^{\mathrm{e}}$ \\ Ana Karina Bezerra Pinheiro $f$
}

D0l: $\quad$ http://dx.doi.org/10.1590/19831447.2015.02.52089

\footnotetext{
aaster of Clinical Nursing Health Care from the Universidade Estadual do Ceará (UECE). PhD student of Nursing at the Federal University of Ceará (UFC), Fortaleza, Ceará, Brazil.

${ }^{b}$ Master's degree student of Nursing at the UFC, Fortaleza, Ceará, Brazil.

c Occupational Nursing Specialist from the Faculdades Integradas de Jacarepaguá. Nurse at the Family Health Strategy, Municipal Health Secretariat, Teresina, Piauí, Brazil.

d Public Health Specialist from the Unidades Integradas de Pós-Graduação Pesquisa e Extensão. Nurse at the State Secretariat of Health of Piauí, Teresina, Piauí, Brazil.

e Doctor of Nursing Practice. Adjunct Professor I, Class $A$, at the UFC, Fortaleza, Ceará, Brazil.

f Doctor of Nursing Practice. Associate Professor II at the UFC, Fortaleza, Ceará, Brazil.
}

\section{ABSTRACT}

Objective: To identify the risk factors for STD among female sex workers and the characteristics of this population, and to verify the association between condom use by their male partners and clients.

Method: Cross-sectional and correlational study conducted with 73 sex workers registered at the Sex Workers' Association of the municipality of Picos - PI, Brazil. Data were collected in September and October 2010 using a questionnaire to obtain sociodemographic information and the participants' background in the sex industry. Ethical aspects were observed.

Results: There was no significant association between most of the sociodemographic variables and background in the sex industry and condom use by male partners or clients. However, there was a significant association with years in the sex industry $(p=0.029)$. Sex workers who had been in the industry for the longest used condoms for protection against sexually transmitted diseases. Conclusion: It is essential to create health promotion strategies that observe the real-life experiences of sex workers. Keywords: Prostitution. Sexually transmitted diseases. Nursing.

\section{RESUMO}

Objetivo: Identificar os fatores de risco para doenças sexualmente transmissíveis em profissionais do sexo e verificar a associação entre uso do preservativo masculino pelo parceiro e pelo cliente e as características dessas mulheres.

Método: Estudo transversal e correlacional, realizado com 73 profissionais do sexo cadastradas na Associação das Profissionais do Sexo do Município de Picos-PI. Para coleta de dados, em setembro e outubro de 2010, utilizou-se formulário contendo questões sociodemográficas e de história de prostituiç̧ão. Os aspectos éticos foram respeitados.

Resultados: A maioria das variáveis sociodemográficas e da história de prostituição não apresentou associação significativa com o uso de preservativo masculino pelo parceiro ou cliente. Entretanto, o tempo de prostituição mostrou associação significativa ( $p=0,029)$. Profissionais do sexo com mais tempo de prostituição adotam o preservativo para proteção contra doenças sexualmente transmissíveis.

Conclusão: É fundamental o desenvolvimento de estratégias direcionadas à realidade vivenciada por elas, com vistas à promoção da saúde das mesmas.

Palavras-chave: Prostituição. Doenças sexualmente transmissíveis. Enfermagem.

\section{RESUMEN}

Objetivo: Identificar los factores de riesgo de enfermedades de transmisión sexual entre trabajadoras sexuales y asociación entre el uso de condones por parte del compañero o cliente y las características de estas mujeres.

Método: Estudio transversal con 73 trabajadoras sexuales registradas en Asociación de Trabajadoras del Sexo en la ciudad de Picos, Piauí. Para recolección de datos, septiembre y octubre de 2010, se utilizó formulario que contiene temas sociodemográficas y de historia de prostitución. Se respetaron los aspectos éticos.

Resultados: Temas sociodemográfica y de historia de prostitución no se asoció significativamente con uso de condones por compañero o cliente. Tiempo de prostitución se asoció de forma significativa $(p=0,029)$. Trabajadoras del sexo, con más tiempo de prostitución, adoptan condón para protegerse contra enfermedades de transmisión sexual.

Conclusión: Es esencial desarrollar estrategias dirigidas a la realidad experimentada por ellos, con el fin de promover la salud de la misma. Palabras clave: Prostitución. Enfermedades de transmisión sexual. Enfermería. 


\section{DINTRODUCTION}

Prostitution is one of the oldest trades in the history of mankind. It is defined as the practice of remunerated sex that does not require an emotional bond between the participating sexual partners ${ }^{(1)}$. Although it is an age-old practice, the category "sex workers" was only included in the Brazilian classification of occupations of the Ministry of Labour and Employment (MTE) in 2002(2).

In spite of this MTE recognition, sex workers are still marginalized and suffer from prejudice and discrimination. They are also exposed to risks that stem from their low socioeconomic condition, such as sexual, physical and psychological violence, alcohol and drug abuse ${ }^{(3-4)}$, and unprotected sex with multiple partners, which is a risk factor for sexually transmitted diseases (STD/AIDS) ${ }^{(5)}$.

LGBT (lesbian, gay, lesbian, bisexual and transgender) sex workers also suffer from prejudice and discrimination, and are especially exposed to the risks of STD/AIDS contamination due to unprotected sex. Research shows that this population has a certain resistance to seeking medical help due to the discrimination, lack of specific training, and the stigma imposed by health professionals to meet this demand(6).

Historically, interventions related to the health of sex workers focus on reducing the risk for acquiring infectious diseases ${ }^{(7)}$. Despite the persist assumption that female prostitutes are the ones who have and spread diseases ${ }^{(8)}$, they are exposed to STD/AIDS that can be transmitted by their clients. Given the steady growth of the global sex industry, a positive attitude in relation to condom use is important to prevent STD/AIDS in this female group ${ }^{(5-9)}$.

Since the 80 s, the Ministry of Health has been adopting strategies to fight the epidemic of human immunodeficiency virus (HIV/AIDS), and partnered with LGBT rights movements to strengthen their participation in the struggle for better health ${ }^{(10)}$. There have been some detectable advancements in programmes and public policies for this specific field, including the National Policy for Integral Women's Health, the Charter for the Rights of Health Users and the National Policy for the Integral Health of $L G B T^{(11)}$.

In relation to prostitution, most countries adopt several approaches that range from policies that focus on punishing prostitution to the creation of non-governmental organizations that educate sex workers on how to prevent STD/AIDS and how to negotiate condom use with their clients ${ }^{(12)}$.

Brazil has extensively adopted the second approach based on the assumption that self-organization and stronger sex worker movements are strategic for sustaining and expanding health care. It is also believed that this approach guarantees the rights of this population and supports STD/AIDS prevention, considering that it helps to strengthen the identity of sex workers and promotes their social and political visibility ${ }^{(2)}$. Consequently, there is a large number of associations for female sex workers, such as the Sex Workers' Association of the municipality of Picos - PI (APROSEP), Brazil, where research for this study was conducted.

In the Philippines, for example, the Department of Health obliges sex workers to register at Social Hygiene Clinics to undergo STD/AIDS testing once a week or every fortnight. Furthermore, as soon as they start working in the sex industry, they must attend an HIV workshop. Some locations have established the mandatory use of condoms in all sexual relations with clients, and the sex workers can be suspended if this rule is violated ${ }^{(9)}$.

In spite of the numerous surveys on the risk factors of STD/AIDS among sex workers, it is important to emphasize that each region has its particularities that may contribute to increasing or reducing the inherent risks of prostitution.

This study is highly relevant for health professionals, sex workers, the scientific community and society as a whole because understanding the main risk factors for STD/AIDS in this population can help to create greater awareness and prevent these diseases more effectively. In addition, and due to the large number of people infected with STD/ AIDS, which are still considered existential risks, this study aims to address the behaviour of sex workers in Picos - Pl, Brazil, in relation to STD/AIDS prevention.

Consequently, the aim of this study is to identify the risk factors for STD among female sex workers and the characteristics of this group, and to verify the association between condom use by their male partners and clients.

\section{METHODOLOGY}

Cross-sectional and correlational study conducted with 73 sex workers registered at the Sex Workers' Association of the municipality of Picos -PI, Brazil. This association was founded in 2004 and aims to promote the health and social well-being of sex workers. For this purpose, the social educators of the association have created a wide range of activities, including the distribution of condoms and educational material, referrals for gynaecological consultations at the Family Health Strategy (FHS), and guidelines on violence, drug use, and other issues.

The study population consisted of 450 women registered at the APROSEP. The sample size was determined 
using the finite population calculation where $95 \%$ confidence interval, $5 \%$ margin of error and $62 \%$ prevalence, which was obtained from a previous study ${ }^{(13)}$. The sampling technique was convenience sampling. The final study sample consisted of 73 female sex workers of the registered areas.

The inclusion criteria were active sex workers in the city of Picos - PI, registered at the APROSEP, and over 18 years of age. The exclusion criteria were use of hallucinogens and currently working at the time of the interview.

Data were collected every day of the week, except Saturday and Sunday, in September and October 2010, at the red-light district registered at the APROSEP. Three trained nursing students collected the data according to the Standard Operational Procedure (POP) created for this study. Social educators of the association accompanied the nurses to the field.

A structured questionnaire was used to collect and record sociodemographic information and the background of the sex workers in the sex industry.

The collected data were tabulated and analyzed using the Statistical Package for Social Sciences (SPSS) version 17.0. The Kolmogorov-Smirnov test for normality was used to describe the sociodemographic data and the background by means of relative and absolute frequencies, averages or medians. For the statistical association of nominal variables, we used the chi-squared test with a value of $p<0.05$
Ethical aspects were observed, according to Resolution 196/96 of the National Health Counci(14). This study was approved by the Research Ethics Committee of the Universidade Federal do Piauí, under protocol 0176.0.045.00-10.

\section{RESULTS}

The sociodemographic characterization of the 73 sex workers we interviewed was based on the variables of marital status, age, income and education. With regard to marital status, the majority (66 - 87\%) of participants was single, 1 (1.3\%) was married, 6 (7.8\%) were divorced, and $3(3.9 \%)$ were widowed. The other variables were listed in Table 1.

According to the Kolmogorov-Smirnov test for normality, the sociodemographic variables age and income did not show a normal distribution and were presented in medians, namely 25 years of age and a monthly income of BRL 500.00, respectively. The only variable that was normal was schooling with an average of 7.9 years of schooling. Based on the resulting medians and averages, no statistical associations were found between these variables and the variable condom use by male partners or clients.

The investigated variables on the background of the sex workers were: time in the industry, sexually transmitted diseases (STD), work-related alcohol use, tobacco use and work-related use of other drugs, as shown in table 2.

Table 1 - Association of sociodemographic variables and the use of condoms by male partners or clients during sexual intercourse. Picos, PI, Brazil, 2010

\begin{tabular}{|c|c|c|c|c|c|c|}
\hline \multirow{3}{*}{ Sociodemographic Variables } & \multicolumn{6}{|c|}{ Condom use during sexual intercourse } \\
\hline & \multicolumn{2}{|c|}{ By the partners } & \multirow{2}{*}{$\mathbf{p}^{*}$} & \multicolumn{2}{|c|}{ By the clients } & \multirow{2}{*}{$\mathbf{p}^{+}$} \\
\hline & Yes & No & & Yes & No & \\
\hline \multicolumn{7}{|l|}{ Age $(n=73)$} \\
\hline Up to 25 years & 07 & 30 & \multirow{2}{*}{0.351} & 36 & 01 & \multirow{2}{*}{0.984} \\
\hline$>25$ years & 04 & 32 & & 35 & 01 & \\
\hline \multicolumn{7}{|l|}{ Education $(n=67)$} \\
\hline Up to 8 years of study & 06 & 29 & \multirow[t]{2}{*}{0.867} & 34 & 01 & \multirow{2}{*}{0.949} \\
\hline$>8$ years of study & 05 & 27 & & 31 & 01 & \\
\hline \multicolumn{7}{|l|}{ Income $(n=73)$} \\
\hline Up to BRL 500.00 & 07 & 32 & \multirow{2}{*}{0.461} & 37 & 02 & \multirow{2}{*}{0.110} \\
\hline$>$ BRL 500.00 & 04 & 30 & & 34 & 00 & \\
\hline
\end{tabular}

Source: Research data, 2010.

*Pearson's chi-squared; 'Likelihood Ratio. 
Table 2 - Association of sociodemographic variables and the use of condoms by male partners or clients during sexual intercourse. Picos, Pl, Brazil, 2010

\begin{tabular}{|c|c|c|c|c|c|c|}
\hline \multirow{3}{*}{ History of prostitution } & \multicolumn{6}{|c|}{ Condom use during sexual intercourse } \\
\hline & \multicolumn{2}{|c|}{ By the partners } & \multirow{2}{*}{$\mathbf{p}^{\dagger}$} & \multicolumn{2}{|c|}{ By the clients } & \multirow{2}{*}{$\mathbf{p}^{+}$} \\
\hline & Yes & No & & Yes & No & \\
\hline \multicolumn{7}{|l|}{ Time $(n=73)$} \\
\hline Up to 01 year & 06 & 17 & \multirow{2}{*}{0.084} & 21 & 02 & \multirow{2}{*}{0.029} \\
\hline$>01$ year & 05 & 45 & & 50 & 00 & \\
\hline \multicolumn{7}{|l|}{ STD $(n=72)$} \\
\hline Yes & 02 & 08 & \multirow{2}{*}{0.564} & 00 & 10 & \multirow{2}{*}{0.58} \\
\hline No & 08 & 54 & & 01 & 61 & \\
\hline \multicolumn{7}{|l|}{ Alcohol (work) (n= 73) } \\
\hline Yes & - & - & \multirow{2}{*}{-} & 58 & 02 & \multirow[t]{2}{*}{0.37} \\
\hline No & - & - & & 13 & 00 & \\
\hline \multicolumn{7}{|l|}{ Tobacco (work) $(n=73)$} \\
\hline Yes & - & - & & 44 & 02 & \multirow{2}{*}{0.170} \\
\hline No & - & - & & 27 & 00 & \\
\hline \multicolumn{7}{|l|}{ Other drugs $(n=73)$} \\
\hline Yes & 01 & 13 & \multirow{2}{*}{0.321} & 14 & 00 & \multirow{2}{*}{0.352} \\
\hline No & 10 & 49 & & 57 & 02 & \\
\hline
\end{tabular}

Source: Research data, 2010.

† Likelihood Ratio.

Most of the investigated industry-related characteristics showed no statistical significance with the variable male condom use by partners or by clients, as shown in table 2 . In relation to years in the industry, most participants, 52 (68.4\%), had been working for over a year. This variable did not present normal distribution in the statistical test, and the observed median was a year. However, it was the only variable that presented a statistical association with the variable male condom use by the clients $(p=0.029)$.

\section{DISCUSSION}

The analysis of sociodemographic characteristics of the study participants showed that, with regard to marital status, most respondents were single, which could support the choice to pursue and continue in this profession. This finding corroborates descriptive research conducted in the southern region of the city of Sao Paulo - SP,
Brazil, were 38 (76\%) of the 50 sex workers were single ${ }^{(4)}$. In contrast, a cross-sectional investigation with 5,498 female sex workers in India showed that slightly over half (52\%) were widows, divorcees or separated, and a third were married ${ }^{(15)}$.

In this study, the other socio-demographic variables (age, education and income) of sex workers did not show a statistically significant association with male condom use by the customer or partner during sex, which can be justified by the small sample size. However, there was a predominance of male condom use by the customers, although the women stated that their partners rarely used condoms

The result above can be related to the issue of fidelity and may symbolize a difference between the professional and personal lives of these women ${ }^{(16)}$. Another possibility for this difficulty to control the use of male condoms can be related to the man's authority ${ }^{(5)}$. This is a worrying factor because, although their partners do not use condoms, 
these women can acquire STD/AIDS and become the transmitters of these diseases.

As for condom use by the customers, this practice can be considered a "social" rule of the establishments, although there is some negotiation and clients may still look for women who do not use condoms if they are willing to pay more for the services ${ }^{(4)}$. This can lead to a significant difference between the answer provided during the interview and the real-life experiences of these workers.

Due to the high number of sexual partners (partners and/or clients), sex workers require guidance on the importance of condom use, whether male or female, during all sexual encounters, and on their empowerment and responsibility in relation with their bodies and lives ${ }^{(17-18)}$. In this context, it is important for health professionals, especially nurses, to provide guidelines to this population in order to reduce the risk of contamination or transmission of STD/AIDS, and the risk of contaminating others.

In relation to age, the median was 25 years old, and the women who were 25 or under reported the most frequent use of condoms among their clients or partners. In the Philippines, a cross-sectional study was conducted with 498 sex workers, of which 142 were included in the analysis of median age, which was 23 years old. The results showed no statistical significance with the negotiation or non-negotiation of condom use with the partners ${ }^{(9)}$.

In other studies, the predominant age of sex workers was also $21-25$ years $(56 \%)^{(4)}$, and the average age was 29.8 years old ${ }^{(15)}$. It was observed that most of the sex workers are younger women. These women could be drawn to this profession because most clients seek the characteristic beauty and youth of this age group ${ }^{(1)}$, which also provides these women with in a more attractive income.

With regard to schooling, average schooling was 7.9 years. This variable was not statistically significant when associated with use of the male condom by partners or clients, although most of the women with up to eight years of schooling reported that both their partners and clients used condoms.

Descriptive analysis, however, showed that 29 (58\%) of the female sex workers had completed their secondary education ${ }^{(4)}$. In the Philippines, the interviewed female sex workers had completed 9 years of studies, although there was no significant statistical association with negotiation or non-negotiation in relation to condom use, as reported in the present study. On the other hand, a cross-sectional study with sex workers in India identified that average years of schooling are $3.9^{(15)}$.
The level of education of sex workers may be associated with their initiation in the red-light district, that is, women with no other qualifications have limited work possibilities and are less likely to get another job.

In relation to income, the median of this variable was BRL 500.00. The participants with an income of BRL 500.00 or less reported the highest frequency of male condom use during sex by their partners or clients. Contrary to this finding, another study showed that $26(46 \%)$ of the interviewed sex workers earned from BRL 1001.00 to BRL $3000.00^{(4)}$.

It should be noted that one of the reasons women chose to become sex workers is limited socioeconomic conditions. However, it was also perceived that their financial conditions do not always improve after they choose to become prostitutes.

It can therefore be inferred that less years of schooling and financial difficulties are obstacles to their integration to other work options. And for those who belong to the lower social classes, the prospects for a change of profession are even less viable due to the lower education levels and lack of occupational training ${ }^{(19)}$.

Among the variables related to prostitution, only years in the industry showed a significant association with male condom use by the clients. This relationship may be because women with more experience in the red-light district develop strategies for negotiating the use of condoms during sexual intercourse.

It was noted that most of the women interviewed had been working for over a year. This finding corroborates clinical research conducted in Moscow, where 49 (33.6\%) of the 147 sex workers had been sex workers for more than 24 months $s^{(7)}$. In another study, almost half of the subjects had been sex workers for 1 to 5 years $(48 \%)^{(4)}$.

With regard to sexually transmitted diseases, the majority of sex workers reported not having any complications, and there was no statistical significance of this finding with male condom use by partners or by the clients. In a qualitative study in Pau dos Ferros - RN, Brazil, only one of the 10 interviewed workers reported the occurrence of an $\mathrm{STD}^{(5)}$.

A study conducted in Mexico with 2401 sex workers identified that the incidence of HIV was 15 times lower among the women who used condoms with customers than among those who did not use condoms ${ }^{(20)}$. This reveals the need to create educational activities for this group of women to promote sexual health and STD/ AIDS prevention.

In addition to STD/AIDS, female sex workers are constantly exposed to other risk factors, such as drug 
and alcohol abuse ${ }^{(4)}$. Thus, the sex workers in this study were investigated in relation to the use of drugs during work. Most of the workers reported the use of alcohol and tobacco, and a few revealed the use of other illegal drugs. None of these three variables had a statistically significant association with male condom use by the clients.

In contrast, research in the southern area of São Paulo - SP, Brazil, revealed a high consumption of drugs among sex workers. The use of legal drugs (cigarettes and alcohol) was reported by more than $31 \%$ of the interviewed workers, while $22 \%$ reported they did not consume any drugs, and the others reported they frequently used cigarettes, alcohol, marijuana, cocaine and LSD (lysergic acid diethylamide) $)^{(4)}$.

The female sex workers tend to associate drug use with their work and claim that the state of alienation caused by these substances helps minimize the discomforts of sexual intercourse ${ }^{(4)}$. In addition, the resulting alterations to their mental state lead to forgetfulness and greater vulnerability, which could be compared to the dangers of not using a condom during sex.

Drug abuse is justified by the easy access, considering that the establishments where these women work encourage high levels of consumption with the hope that clients will also consume and subsequently increase their profits ${ }^{(4)}$.

The findings listed above reveal the need for health professionals, especially nurses of the Family Health Strategy, to create health education strategies that focus on preventing STD/AIDS by showing the importance of male or female condom use during sex.

\section{- CONCLUSIONS}

The limitations of this study were the small number of participants, which did not allow a statistical association of male condom use by regular partners or clients with risk variables for STD/AIDS. This number could have been extended, considering that the studied population was of 450 sex workers, but many of the women refused to participate in the study because of the social stigma and fear of exposure although they were guaranteed anonymity and confidentiality.

Therefore, the only established relationship was years in the sex industry and this could be associated to the experience of these sex workers in negotiating condom use with their clients.

This finding supports the need for guidance and counselling provided by healthcare professionals, especially nurses of the Family Health Strategy, on STD/
AIDS transmission and prevention based on the active follow-up of gynaecological consultations and the promotion of health among women who work in the sex industry. These actions should be based on intersectoral collaboration that involves the sex worker associations, and health education that focuses on the real needs of these women.

\section{REFERENCES}

1. Penha JC, Cavalcanti SDC, Carvalho SB, Aquino PS, Galiza DDF, Pinheiro AKB. Características da violência física sofrida por profissionais do sexo no interior piauiense. Rev Bras Enferm. 2013;65(6):984-90.

2. Ministério da Saúde (BR). Recomendações da consulta nacional sobre DST/aids, direitos humanos e prostituição. Brasília: Ministério da Saúde; 2012.

3. Neri EAR, Moura MSS, Penha JC, Reis TGO, Aquino PS, Pinheiro AKB. Conhecimento, atitude e prática sobre o exame Papanicolaou de profissionais do sexo. Texto Contexto Enferm. 2013;22(3):731-8.

4. Salmeron NA, Pessoa TAM. Profissionais do sexo: perfil socioepidemiológico e medidas de redução de danos. Acta Paul Enferm. 2012;25(4):549-54.

5. Paiva LL, Araújo JL, Nascimento EGC, Alchieri JC. As vivências das profissionais do sexo. Saúde Debate. 2013;37(98):467-76.

6. Barbosa RM, Facchini R. Acesso a cuidados relativos à saúde sexual entre muIheres que fazem sexo com mulheres em São Paulo, Brasil. Cad Saúde Pública. 2009;25(supl 2):291-300.

7. Decker MR, Yan EA, Wirtz Al, Baral SD, Peryshkina A, Mogilnyi V, et al. Induced abortion, contraceptive use, and dual protection among female sex workers in Moscow, Russia. Int J Gynaecol Obstet. 2013;120(1):27-31.

8. Silva CM, Lopes FMVM, Vargens OMC. A vulnerabilidade da mulher idosa em relação à AIDS. Rev Gaúcha Enferm. 2010;31(3):450-7.

9. Urada LA, Morisky DE, Pimentel-Simbulan N, Silverman JG, Strathdee SA. Condom negotiations among female sex workers in the Philippines: environmental influences. PLoS One. 2012;7(3):e33282.

10. Ministério da Saúde (BR). Política nacional de saúde integral de lésbicas, gays, bissexuais, travestis e transexuais. Brasília: Ministério da Saúde; 2010.

11. Albuquerque GA, Garcia CL, Alves MJH, Queiroz CMHT, Adami F. Homossexualidade e o direito à saúde: um desafio para as políticas públicas de saúde no Brasil. Saúde Debate. 2013;37(98):516-24.

12. Kaufman J. HIV, sex work, and civil society in China. J Infect Dis. 2011;204(Suppl 5):1218-22.

13. Ximenes Neto FRG, Oliveira JS, Rocha J. Violência sofrida pelas profissionais do sexo durante seu trabalho e as atitudes tomadas após serem vitimadas. Rev Min Enferm. 2007;11(3):248-53.

14. Ministério da Saúde (BR). Conselho Nacional de Saúde. Resolução no 196, de 10 de outubro de 1996. Diretrizes e normas regulamentadoras de pesquisas envolvendo seres humanos. Diário Oficial [da] República Federativa do Brasil. 1996 out.16;134(201 Seção 1):21082-5.

15. Swain SN, Saggurti N, Battala M, Verma RK, Jain AK. Experience of violence and adverse reproductive health outcomes, HIV risks among mobile female sex workers in India. BMC Public Health. 2011;11:357.

16. Moura ADA, Pinheiro AKB, Barroso MGT. Realidade vivenciada e atividades educativas com profissionais do sexo: subsídios para a prática de enfermagem. Esc Anna Nery. 2009;13(3):602-8. 
17. Meis C. Cultura e empowerment: promoção à saúde e prevenção da aids entre profissionais do sexo no Rio de Janeiro. Ciênc Saúde Coletiva. 2011;16(supl. 1):1437-44.

18. Gomes VLO, Fonseca AD, Jundi MG, Severo TP. Percepções de casais heterossexuais acerca do uso da camisinha feminina. Esc Anna Nery. 2011;15(1):22-30.
19. Moura ADA, Oliveira RMS, Lima GG, Farias LM, Feitoza AR. O comportamento de profissionais do sexo em tempos de aids e outras doenças sexualmente transmissíveis: como estão se prevenindo? Texto Contexto Enferm. 2010;19(3):545-53.

20. Bórquez A, HalletTB, Gomes GB, Garnett GP. Condom use by female sex workers and their clients in Mexico: who decides and does it matter? Sex Transm Infect. 2011;87(3):254-6.

\section{Author's address:}

Jardeliny Corrêa da Penha

Rua Coelho Rodrigues, 350, Ibiapaba

64800-000 Floriano - PI

E-mail: jardelinypenha@yahoo.com.br
Received: 02.12.2014

Approved: 19.03.2015 